\title{
Isolation and identification of microorganisms in Kazakhstan koumiss and their application in preparing cow-milk koumiss
}

\author{
Aizhan Rakhmanova, $\bullet$ Tao Wang, Guo Xing, Lingling Ma, Yan Hong, Yingying Lu, Li Xin, Wang Xin, \\ Qiao Zhu, and Xin Lü* (D) \\ College of Food Science and Engineering, Northwest A \& F University, Yangling, Shaanxi Province, China 712100
}

\begin{abstract}
Koumiss is a type of famous fermented mare milk and considered an important nutritious beverage in central Asian countries. However, the production of koumiss cannot meet public demand in the market due to availability of mare milk. In the present study, 52 lactic acid bacteria and 20 yeast strains from traditional homemade Kazakhstan koumiss were isolated and identified. The isolates were used in a trial that included fermented cow milk, and the flavor profiles, color, and taste to determine their contribution in the co-fermentation of cow milk. Based on the sensory evaluation, KZLAB13 and KZY10 strains were selected as the best cofermentation combinations. The optimal fermentation conditions were confirmed as the ratio of the starter culture 2.4:1.6\% (vol/vol) KZLAB13 strain to KZY10 strain and a temperature of $36^{\circ} \mathrm{C}$ for $16 \mathrm{~h}$ using response surface methodology. After evaluating the quality of the optimized cow-milk koumiss compared with the Kazakhstan koumiss, results suggested that cow milk fermented by these 2 strains possessed a promising taste, flavor, and physicochemical and rheological properties. Altogether, our results showed that cow milk fermented with a combination of KZLAB13 and KZY10 strains can simulate the taste, flavor, and quality of traditional koumiss. Our study provided a novel alternative to mare-milk koumiss and could be used in dairy programs to fulfill the needs of people.

Key words: fermentation, flavor compound, koumiss, microorganism, optimization
\end{abstract}

\section{INTRODUCTION}

Koumiss (kumis, kymyz, or qymyz) is a fermented mare milk that is famous in central Asian countries. In Kazakhstan, koumiss is a national beverage commonly

Received March 13, 2020.

Accepted September 16, 2020.

*Corresponding author: xinlu@nwsuaf.edu.cn produced in wooden casks and containers by adding fresh mare milk to a wooden cask containing a small amount of koumiss as a starter culture at room temperature (Hui and Evranuz, 2012). The taste of koumiss is sour; it contains alcohol due to the presence of a high proportion of sugar in mare milk that ferments into lactic acid, alcohol, and other small molecules by microbial fermentation. It was reported that koumiss is fermented by the symbiosis of at least 2 main distinct microorganisms including lactic acid bacteria (LAB) and yeast (Montanari et al., 1996; Cagno et al., 2004), causing the unique flavor, texture, and acidity level, as well as health benefits of koumiss. Therefore, microorganisms contained in the koumiss are important for the quality of its fermentation (Dönmez et al., 2014). It has been found that protein, fat, lactose, minerals, enzymes, vitamins, and pigments are the main components of koumiss (Malacarne et al., 2002; Danova et al., 2005). Compared with other fermented milk, koumiss possesses almost all essential AA and high vitamin $\mathrm{C}$ levels that are important for humans (Park et al., 2006a; Bornaz et al., 2010). Beneficial effects, such as regulation of the alimentary canal activity, improved kidney function, and reduced blood cholesterol levels, also make koumiss a famous beverage in central Asia (Cagno et al., 2004; Mu et al., 2012; Dhewa et al., 2015). In this respect, mare milk is very well known in ethnomedicine and is an important component of the traditional diet of Asian steppe people, among whom consumption of mare milk is culturally and environmentally rooted (Langlois, 2011; Ishii et al., 2014). Owing to some beneficial characteristics including low cholesterol levels and a rich amount of polyunsaturated fatty acids, mare milk in the human diet has received more attention in Europe, France, and, in particular, Germany (Park et al., 2006b; Doreau and Martin-Rosset, 2011; Salimei and Park, 2017).

The cost of mare milk has been a major factor for its use, and the availability falls short of the demand even in the traditional home countries of koumiss production. Moreover, it is hard to control the quality of koumiss made by traditional craftsmanship. Therefore, 
it is of extreme importance to exploit novel koumiss alternatives to meet daily life requirements of koumiss consumers (Kücükcetin et al., 2003). Cow milk is commonly used around the world for making dairy products, which is not only considered to be a low-cost dairy milk, but also rich in nutrient content that stimulates our metabolic activity and improves our health. On the other hand, cow milk is a good source of protein, which makes it highly efficient in the fermentation process. This suggests that cow milk may be the most promising mare-milk alternative to produce koumiss, particularly in developing countries.

Because of the growing demand for koumiss consumption numerous strains of $\mathrm{LAB}$ and yeast were isolated and identified from Kazakhstan koumiss in the present research. Additionally, $1 \mathrm{LAB}$ and 1 yeast strain were selected for fermenting the cow milk to influence the taste of traditional koumiss by using response surface methodology (RSM). Further, volatile flavor substances formed during cow-milk fermentation were determined by GC-MS methodology and compared with Kazakhstan koumiss. The results of the present study will facilitate the production of koumiss by using cow milk as an alternative to mare milk.

\section{MATERIALS AND METHODS}

\section{Collection of Samples}

In this study, koumiss was collected from Kazakhstan that was produced by the local artisanal producers. The samples were collected in sterile bottles and transferred to the laboratory for microbiological analysis and stored aseptically at $4^{\circ} \mathrm{C}$ for further analysis.

\section{Isolation of $L A B$ and Yeasts and Microbiological Analysis}

One milliliter of koumiss sample was added to a flask and mixed with $99 \mathrm{~mL}$ of sterile distilled water. Appropriate dilutions of $10^{-1}$ to $10^{-7}$ were carried out in the sterile water. The LAB strains were isolated on the deMan, Rogosa, and Sharpe (MRS) agar medium, and yeasts on the yeast extract peptone dextrose (YPD) agar media. Plates were incubated at $37^{\circ} \mathrm{C}$ for $\mathrm{LAB}$ and $28^{\circ} \mathrm{C}$ for yeast screening. The predominant, morphologically distinct, and well-isolated colonies of LAB were transferred to MRS agar plates and yeasts to the YPD agar plates for further enrichment.

All isolated strains from koumiss were morphologically characterized by cell morphology and Gram staining (Norris et al., 1981) as well as biochemically characterized for catalase and oxidase testing before stock preparation (Nair and Surendran, 2005). Purified
LAB strains were kept in MRS broth and yeasts kept in YPD broth supplemented with $20 \%$ (vol/vol) glycerol and stored at $-40^{\circ} \mathrm{C}$.

\section{Identification of the Strains}

The LAB strains were cultured in the MRS medium at $37^{\circ} \mathrm{C}$ for $24 \mathrm{~h}$, after which cells of the strains were harvested by centrifugation and the genomic DNA of strains were extracted using a genome DNA isolation kit (Sangon Biotech, Shanghai, China). Further, the $16 \mathrm{~S}$ rRNA gene was amplified using the universal primer $27 \mathrm{~F}$ (5'-AGAGTTTGATCMTGGCTCAG-3') and primer 1492R (5'-TACGGYTACCTTGTTACGACTT$\left.3^{\prime}\right)$. We performed PCR by applying the $2 \times$ Taq Master Mixture (Shanghai, China). For amplification reaction, 1 mixture was prepared in a $200-\mu \mathrm{L}$ tube that contained $6.5 \mu \mathrm{L}$ of double-distilled (dd) $\mathrm{H}_{2} \mathrm{O}, 2 \mu \mathrm{L}$ of primer $27 \mathrm{~F}, 2 \mu \mathrm{L}$ of $1492 \mathrm{R}$ (Table 1), $2 \mu \mathrm{L}$ of genomic DNA, and $12.5 \mu \mathrm{L} 2 \times$ Taq Master Mixture. The PCR amplification program was performed as described (denaturation at $94^{\circ} \mathrm{C}$ for 5 min, 35 cycles of denaturation $94^{\circ} \mathrm{C}$ for $1 \mathrm{~min}, 72^{\circ} \mathrm{C}$ for $3 \mathrm{~min}$, and a final extension at $72^{\circ} \mathrm{C}$ for $10 \mathrm{~min}$ ) by Dertli et al. (2016) and then run as follows. The amplified gene fragment was separated by gel electrophoresis using 1.5\% (wt/vol) agarose gel and recovered using a gel extraction kit (Sangon Biotech). Amplified 16S rRNA genes were sequenced by Aoke Company (Yangling, China), and the 16S rRNA gene sequence was identified using the BLAST program developed by the National Center for Biotechnology Information (NCBI; https://blast.ncbi.nlm.nih.gov/Blast .cgi). Phylogenetic analysis was performed by using MEGA X with 100 bootstrap replicates (Saitou and Nei, 1987; Tamura et al., 2011).

For genomic DNA extraction, yeast cells were grown in YPD broth at $28^{\circ} \mathrm{C}$ on a turning shaker and collected by centrifugation. A genome DNA isolation kit (Sangon Biotech) was used to extract the genomic DNA of yeasts by following the method of Makimura et al. (1994). Amplification of the 26S rRNA gene through PCR was done by using primers ITS1 (5' TCCGTAGGTGAACCTGCGG $3^{\prime}$ ) and primer ITS4 (5' TCCTCCGCTTATTGATATGC $3^{\prime}$ ). For the amplification reaction, 1 mixture was prepared in a $200-\mu \mathrm{L}$ tube that

Table 1. Primers used for $16 \mathrm{~S}$ rRNA and 26S rRNA sequencing

\begin{tabular}{ll}
\hline Primer & Sequences $\left(5^{\prime}-3^{\prime}\right)$ \\
\hline $27 \mathrm{~F}$ & 5'-AGAGTTTGATCMTGGCTCAG-3' \\
$1492 \mathrm{R}$ & 5'-TACGGYTACCTTGTTACGACTT-3' \\
ITS1 & 5'-TCCGTAGGTGAACCTGCGG-3' \\
ITS4 & 5'-TCCTCCGCTTATTGATATGC-3' \\
\hline
\end{tabular}


contained $6.5 \mu \mathrm{L}$ of dd $\mathrm{H}_{2} \mathrm{O}, 2 \mu \mathrm{L}$ of primer ITS1, $2 \mu \mathrm{L}$ of ITS4, $2 \mu \mathrm{L}$ of genomic DNA isolated from koumiss, and $12.5 \mu \mathrm{L} 2 \times$ Taq Master Mixture. Amplification was performed in a PTC- 200 Peltier thermal cycler programmed as follows: $94^{\circ} \mathrm{C}$ for 3 min, then 35 cycles of $94^{\circ} \mathrm{C}$ for $30 \mathrm{~s}, 52^{\circ} \mathrm{C}$ for $30 \mathrm{~s}$, and $74^{\circ} \mathrm{C}$ for $2 \mathrm{~min}$, followed by $74^{\circ} \mathrm{C}$ for $10 \mathrm{~min}$. The PCR product was separated by $1.5 \%$ (wt/vol) agarose gel electrophoresis, and the DNA was recovered by a DNA gel extraction kit (Sangon). Amplified 26S rRNA genes were sequenced by Aoke Company, and the $26 \mathrm{~S}$ rRNA gene sequence was identified using the BLAST program. The sequences were used for the phylogenetic analysis using MEGA X with 100 bootstrap replicates (Saitou and Nei, 1987).

\section{Selection of Best $L A B$ and Yeasts Combinations}

First, all identified LAB strains (Supplemental Table S1, https://doi.org/10.3168/jds.2020-18527) from traditional koumiss samples were individually inoculated with the MRS medium incubated at $37^{\circ} \mathrm{C}$ for $24 \mathrm{~h}$. The process was repeated several times umtil the viability of bacteria became stable. For milk inoculation, the tube containing the bacterial suspension was centrifuged $\left(4,000 \times g, 4^{\circ} \mathrm{C}, 3 \mathrm{~min}\right)$. Thereafter, cells were harvested and washed twice with $0.1 \mathrm{M} \mathrm{NaCl}$ solution for milk fermentation. The milk fermentation was processed using low-fat $(1.5 \%)$ cow milk. All samples were incubated at $37^{\circ} \mathrm{C}$ until the curd occurred (Papadopoulou et al., 2019). At the end of incubation, the fermented cow milk was evaluated for sensory characteristics such as taste, color, and flavor. The sensory attributes of the samples were evaluated by the 10 panelists, and the strain that contributed to the highest sensory value was selected for further investigation. Second, to find the best combination of the LAB with yeast strain to ferment the cow milk, the previously selected LAB strain was inoculated with different isolated yeasts. All yeast strains were individually inoculated in YPD medium and incubated at $28^{\circ} \mathrm{C}$ for $24 \mathrm{~h}$. For the selection of the best yeast strain, the same method has done as described above (Supplemental Table S2, https://doi .org/10.3168/jds.2020-18527). The total inoculum size was $6 \%$ ( $\mathrm{vol} / \mathrm{vol})$, and the ratio between $\mathrm{LAB}$ and yeast was $1: 1$ ( $\mathrm{vol} / \mathrm{vol})$.

\section{Optimization of Cow-Milk Koumiss}

One Factor at a Time Experimental Design. The effects of different fermentation time $(7,10,13$, 16, 19, and $21 \mathrm{~h}$ ), fermentation temperature $(24,28$, $32,36,40$, and $44^{\circ} \mathrm{C}$ ), and total inoculation size [4, $1,1,4,7$, and $10 \%$ ( $\mathrm{vol} / \mathrm{vol})]$ on the sensory value of fermented milk production were investigated by singlefactor experiments. The ratios of KZLAB13 strain to KZY10 strain tested were 1.6:2.4, 0.4:0.6, 0.6:0.4, 2.4:1.6, 4.2:2.8, and 6:4\% (vol/vol). Strains fermented at a constant temperature at $36^{\circ} \mathrm{C}$ for $16 \mathrm{~h}$. The sensory evaluation was applied at the end of each process (Wang et al., 2019). The results of the preliminary screening could provide the required information for the RSM optimization experiment.

Response Surface Methodology: Box-Behnken Design. To further obtain the optimal level of the main fermentation parameters and study their interactions on the quality of fermented products, the RSM method was applied. Based on the results of the one factor at a time experiment, the 3 most effective factors $\left(\mathbf{X}_{1}\right.$, fermentation temperature; $\mathbf{X}_{2}$, inoculation size, and $\mathbf{X}_{3}$, fermentation time) were studied in 3-level codes: $-1,0$, and +1 . In the present study, we used the Box-Behnken design for the optimization of fermentation conditions of the studied fermented product. The design consisted of 17 randomly performed experiments, and the results related to the effect of the different factors on the development of koumiss from cow milk are shown in Table 2. The experiments were conducted in a $250-\mathrm{mL}$ glass jar containing $100 \mathrm{~mL}$ of milk. The sensory quality of the fermented cow milk was evaluated as the responses for the studied factors. The quality of the fermented cow-milk koumiss was rated based on the sensory evaluation $\left(\mathbf{Y}_{\mathbf{1}}\right)$ as responded by the panelists. The optimal fermentation conditions were calculated by testing the empirical second-order polynomial regression model. The following second-order polynomial equation describes the relationship between the dependent and independent variables as follows:

$$
\begin{gathered}
Y=\beta_{0}+\beta_{1} A+\beta_{2} B+\beta_{3} C+\beta_{11} A^{2}+\beta_{22} B^{2}+\beta_{33} C^{2} \\
+\beta_{12} A B+\beta_{13} A C+\beta_{23} B C,
\end{gathered}
$$

where $Y$ is the predicted response; $\beta_{0}$ is the intercept; $\beta_{1}, \beta_{2}$, and $\beta_{3}$ are the linear coefficients; $\beta_{11}, \beta_{22}$, and $\beta_{33}$ are the squared coefficients; and $\beta_{12}, \beta_{13}$, and $\beta_{23}$ are the interaction coefficients. Design Expert software (version 8.0.5, Stat-Ease Inc., Minneapolis, MN) was used for the experimental design and statistical analysis, while $A, B$, and $C$ are coefficients.

The Bradford Method to Determine Protein Content. The protein contents were determined using the Bradford assay (Cheng et al., 2016). Initially, the Bradford solution was prepared and kept at $4^{\circ} \mathrm{C}$. We mixed $100 \mu \mathrm{L}$ of the sample with $5 \mathrm{~mL}$ of Bradford solution and incubated it at room temperature for 5 min. After, the absorbance value was measured at 595 
nm. A standard solution of BSA $(0,0.0625,0.125,0.25$, 0.5 and $1 \mathrm{~g} / \mathrm{L}$ ) was used to prepare a calibration curve.

Plate Count Method to Determine LAB and Yeast Population in Traditional Kazakhstan Koumiss and Cow-Milk Koumiss. The serial dilutions of the samples were made and the suspension was spread onto MRS and YPD agar plates. The plates were then incubated at $37^{\circ} \mathrm{C}$ and $28^{\circ} \mathrm{C}$, respectively. Growth was observed by counting the colonies, and the results were expressed as colony-forming unit per milliliter.

Measurement of $p H$ and Total Acidity. The pHSJ- 3F meter was used to determine the $\mathrm{pH}$ of the samples at room temperature (Leici, Shanghai, China). The total acidity of the fermented samples was determined by the titration method as suggested by Dan et al. (2019).

\section{Sensory Evaluation}

The method described by the Criterion for Sensory Evaluation of Fermented Milk (RHB 04-2020, issued by China's dairy industry standards, http://news .foodmate.net/2020/04/556069.html) was used to evaluate the sensory evaluations and the organoleptic characteristics of the samples. Ten trained panelists were selected for the evaluation of the sensory characteristics of the cow-milk koumiss. The samples were served at $4^{\circ} \mathrm{C}$ in cups and labeled with numbers. The panel was asked to provide individual scores on a 10 to 30 scale for color (white, milky white, and slightly yellow), a 10 to 40 scale for flavor (light sour smell, sour smell, and bad smell), and a 10 to 30 scale for taste (millet taste, slightly millet taste, and bitter taste). Three replicates were used for each sample in each session, and the mean for each sample was calculated (Wang et al., 2019).

\section{Rheological Measurements}

The rheometer (AR1000, TA instruments, New Castle, DE) with a 20-mm parallel plate was used for the identification of rheological properties of Kazakhstan koumiss, cow-milk koumiss, and milk samples. The replicate measurements were taken independently, and the RheoWin Pro software package (version 2.94, Thermo Haake, Karlsruhe, Germany) was used for data analysis. Strain sweep $(0.01-100 \%$ at $1 \mathrm{~Hz})$ was applied to test the linear viscoelastic region of the samples. Further, the frequency dependence of storage modulus $\left(\mathbf{G}^{\prime}\right)$ and loss modulus $\left(\mathbf{G}^{\prime \prime}\right)$ was determined by a frequency sweep $(0.1-10 \mathrm{~Hz}$ at $1 \%$ strain; Wang et al., 2014).

\section{Gas Chromatographic Analysis for Determining the Ethanol Content}

About $3 \mathrm{~g}$ of Kazakhstan koumiss and cow-milk koumiss samples were weighed and homogenized with a blender, and centrifuged at $4,000 \times g$ for $5 \mathrm{~min}$. Thereafter, the supernatant was filtered through a $0.22-\mu \mathrm{L}$ disposable syringe membrane filter (Xian, China) and subsequently injected directly into the gas chromatographic apparatus. The reagent ethanol was used as a standard. A diluent-standard solution was prepared by diluting ethanol to $0.05 \%$ ( $\mathrm{vol} / \mathrm{vol}$ ) with distilled water. The diluent solution was stoppered and stored at $-20^{\circ} \mathrm{C}$. The ethanol content in the samples was measured by gas chromatography (Perkin Elmer Head-

Table 2. The matrix of Box-Behnken design, analyzed using Design Expert 8 (version 8.0.5, Stat-Ease Inc., Minneapolis, MN)

\begin{tabular}{|c|c|c|c|c|c|c|}
\hline Standard & Run & $\begin{array}{l}\text { Inoculum } \\
\text { size }\left(X_{1}\right)\end{array}$ & $\begin{array}{c}\text { Temperature } \\
\qquad\left(X_{2}\right)\end{array}$ & $\begin{array}{l}\text { Time } \\
\left(X_{3}\right)\end{array}$ & $\begin{array}{c}\text { Actual } \\
\text { (sensory evaluation) }\end{array}$ & $\begin{array}{l}\text { Predicted } \\
\text { value }\end{array}$ \\
\hline 6 & 1 & $1.00(7 \mathrm{~g} / \mathrm{L})$ & $0.00\left(36^{\circ} \mathrm{C}\right)$ & $-1.00(12 \mathrm{~h})$ & 62 & 41.62 \\
\hline 3 & 2 & $-1.00(1 \mathrm{~g} / \mathrm{L})$ & $1.00\left(40^{\circ} \mathrm{C}\right)$ & $0.00(16 \mathrm{~h})$ & 67 & 74.32 \\
\hline 14 & 4 & 0.00 & 0.00 & 0.00 & 90 & 80.38 \\
\hline 12 & 5 & 0.00 & 1.00 & $1.00(20 \mathrm{~h})$ & 56 & 44.25 \\
\hline 5 & 6 & -1.00 & 0.00 & -1.00 & 39 & 60.50 \\
\hline 8 & 9 & 1.00 & 0.00 & 1.00 & 75 & 43.13 \\
\hline 4 & 10 & 1.00 & 1.00 & 0.00 & 77 & 75.13 \\
\hline 17 & 11 & 0.00 & 0.00 & 0.00 & 91 & 61.88 \\
\hline 2 & 12 & 1.00 & -1.00 & 0.00 & 71 & 57.88 \\
\hline 7 & 13 & -1.00 & 0.00 & 1.00 & 35 & 91.80 \\
\hline 11 & 14 & 0.00 & -1.00 & 1.00 & 60 & 91.80 \\
\hline 1 & 15 & -1.00 & -1.00 & 0.00 & 45 & 91.80 \\
\hline
\end{tabular}


space sampler HS 40XL, Perkin Elmer Auto system Gas Chromatograph equipped with Ionization Detector FID, Akron, $\mathrm{OH}$ ) as previously used by Macciola et al. (2008).

\section{Solid Phase Microextraction GC-MS Analysis}

Volatile organic compounds (VOC) from Kazakhstan koumiss, cow-milk koumiss, and milk were analyzed using the headspace solid phase microextraction technique (Dan et al., 2017). Five milliliters of each sample was placed into a $20-\mathrm{mL}$ headspace vial containing $2 \mathrm{~g}$ of $\mathrm{NaCl}$ and $20 \mu \mathrm{L}$ of n-hexadecane as the internal standard; after that, vials sealed rapidly. A $50 / 30 \mu \mathrm{m}$ DVB/CAR/PDMS fiber (Supelco, Bellefonte, PA) was used to carry the solid phase microextraction procedure. The GC-MS procedure was accomplished by using 7890A-5975C (Agilent Technologies, Santa Clara, CA). A capillary column (HP-5 $\mathrm{ms}, 30 \mathrm{~m} \times 250 \mu \mathrm{m} \times 0.25 \mu \mathrm{m}$, Agilent Technologies) was used with helium as a carrier gas at $1.0 \mathrm{~mL} / \mathrm{min}$ flow rate. The oven temperature was set at $40^{\circ} \mathrm{C}$ for 3 min, increased to $120^{\circ} \mathrm{C}$ at a rate of $4^{\circ} \mathrm{C} / \mathrm{min}$, and then increased further to $240^{\circ} \mathrm{C}$ at a rate of $6^{\circ} \mathrm{C} / \mathrm{min}$ for 12 min. A final 3-min extension was performed at $250^{\circ} \mathrm{C}$. The ion source and the transfer line temperatures were set at $230^{\circ} \mathrm{C}$ and $250^{\circ} \mathrm{C}$, respectively. The National Institute of Standards and Technology (NIST) mass spectral search program (version 2.0; https://www.nist .gov/srd/nist-standard-reference-database-1) was applied to evaluate the results by comparing their mass spectra. The quantitative relative concentration of each volatile compound was calculated by using the internal standard for all samples. To calculate the concentration of the analyte in the sample, the peak area of the analyte in the sample was divided by the peak area of n-hexadecane and multiplied by the concentration of n-hexadecane.

\section{Statistical Analysis}

All experiments were carried out in triplicate, and all analyses were carried out once. For optimization of fermentation parameters, the statistical software package Design Expert (Stat-Ease, Inc.) was used, and 3-dimensional response surface plots were produced to elucidate the relationships between the responses and the experimental levels of each independent variable. The statistical competence of the model was determined through ANOVA, presented in Table 3. The F- and $P$-values were used to test the significance of each factor and regression model. The excellence of the polynomial model equation was determined statistically through the coefficient of determination $\left(\mathbf{R}^{2}\right)$ and the adjusted $R^{2}$. Significant differences between the mean values in physicochemical characteristics of Kazakhstan koumiss and cow-milk koumiss were determined by Student's t-test using the Statistix software version 10 (https://www.statistix.com/). For VOC of Kazakhstan koumiss and cow-milk koumiss, multiple comparisons were performed using one-way ANOVA, followed by posthoc testing using Tukey's multiple comparisons test. A value of $P<0.05$ was regarded as statistically significant. Data are presented in Tables 4 and 5 as the mean \pm standard deviation of at least 3 independent experiments.

Table 3. ANOVA of the quadratic model for the sensory evaluation, analyzed using Design Expert 8 (version 8.0.5, Stat-Ease Inc., Minneapolis, $\mathrm{MN})$

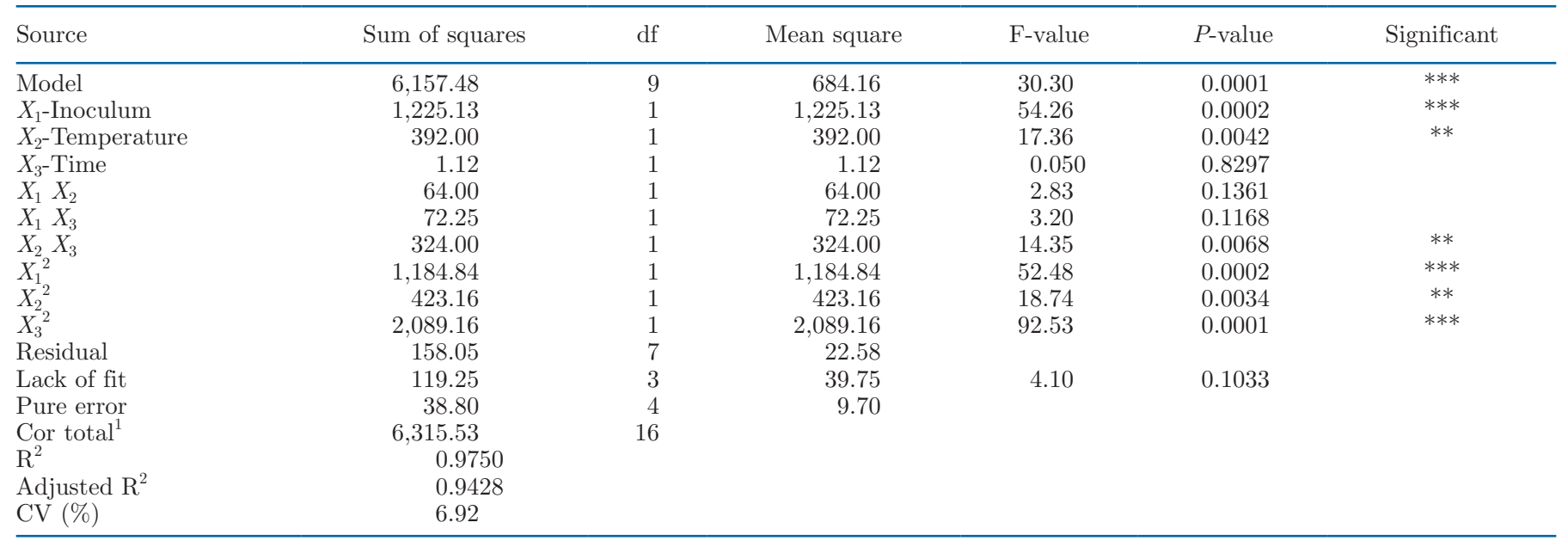

${ }^{1}$ Cor $=$ corrected total sum of squares.

*, **, and *** represent $P<0.05, P<0.01$, and $P<0.001$, respectively. 
Table 4. Comparison of physicochemical and microbiological properties of Kazakhstan koumiss and cow-milk koumiss ${ }^{1}$

\begin{tabular}{|c|c|c|c|c|c|c|}
\hline Sample & Acidity $\left({ }^{\circ} \mathrm{T}\right)$ & $\mathrm{pH}$ & Ethanol (\%) & Protein $(\%)$ & $\begin{array}{c}\text { Lactic acid } \\
\text { bacteria }(\mathrm{cfu} / \mathrm{mL})\end{array}$ & Yeast (cfu/mL) \\
\hline Kazakhstan koumiss & $97.40 \pm 8.83^{\mathrm{a}}$ & $3.41 \pm 0.08^{\mathrm{a}}$ & $2.12 \pm 0.24^{\mathrm{a}}$ & $1.95 \pm 0.13^{\mathrm{a}}$ & $2.24 \pm(0.26) \times 10^{8 \mathrm{a}}$ & $2.41 \pm(0.40) \times 10^{6 \mathrm{a}}$ \\
\hline Cow-milk koumiss & $71.67 \pm 8.02^{\mathrm{b}}$ & $4.33 \pm 0.01^{\mathrm{b}}$ & $0.50 \pm 0.08^{\mathrm{b}}$ & $2.77 \pm 0.24^{\mathrm{b}}$ & $9.90 \pm(0.16) \times 10^{8 \mathrm{~b}}$ & $1.14 \pm(0.19) \times 10^{6 \mathrm{~b}}$ \\
\hline
\end{tabular}

${ }_{\mathrm{a}, \mathrm{b}}$ Superscript letters in the same column indicate significant differences $(P<0.05)$.

${ }^{1}$ Data are presented as the mean $\pm \mathrm{SD}$ of 3 independent experiments. Statistical analyses were carried out by the Student's $t$-test.

Table 5. Volatile organic compounds $(\mu \mathrm{g} / \mathrm{L})$ quantified from Kazakhstan koumiss, cow-milk koumiss, and milk ${ }^{1}$

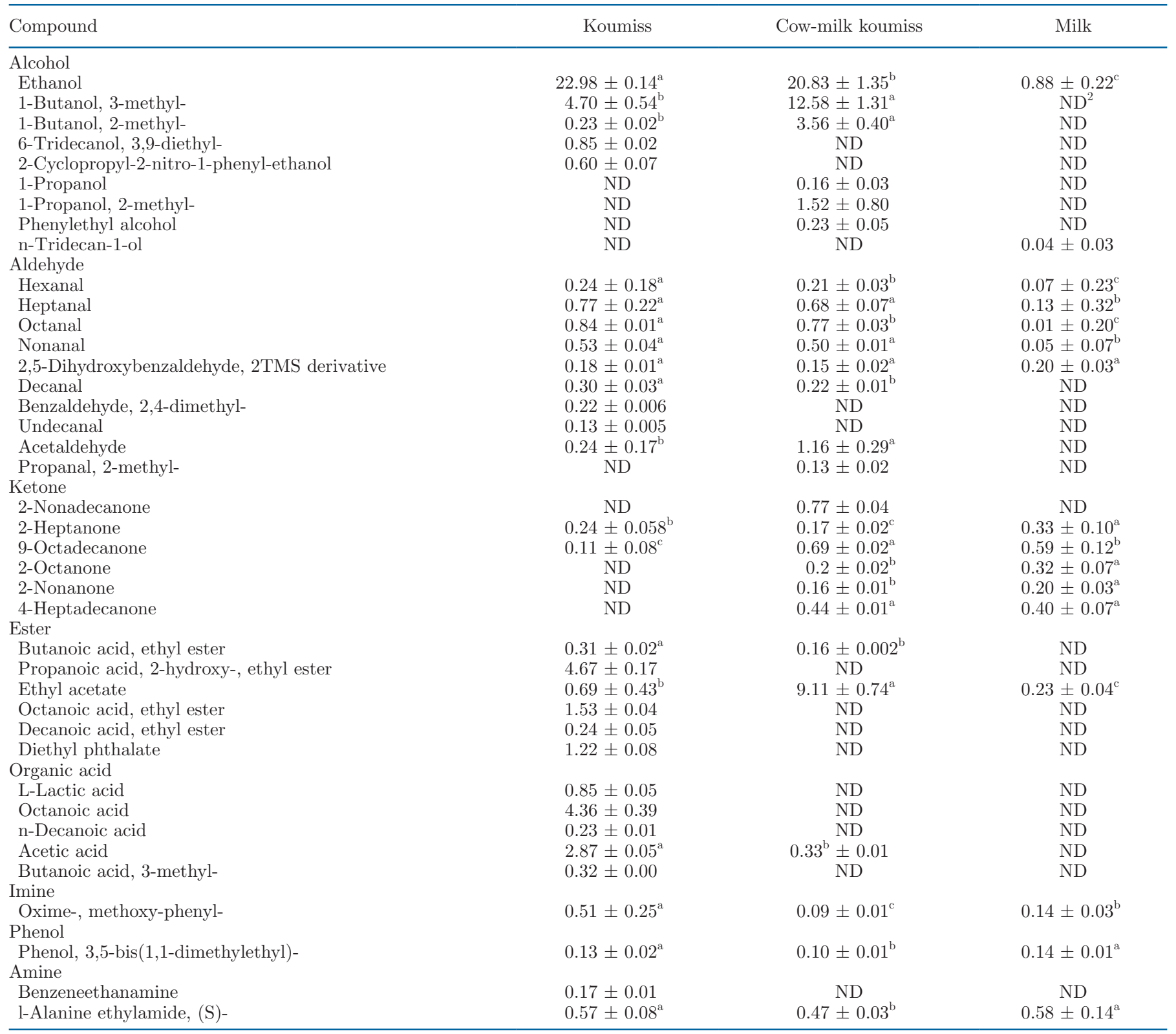

${ }^{\mathrm{a}-\mathrm{c}}$ Different superscript letters in the same row indicate significant differences.

${ }^{1}$ All data were expressed as the mean $\pm \mathrm{SD}$ of 3 independent experiments. Statistical analyses were carried out by Tukey's multiple comparison test $(P<0.05)$. The author analyzed experiment data using Statistix version 10 (https://www.statistix.com/).

${ }^{2} \mathrm{ND}=$ not detected. 


\section{RESULTS AND DISCUSSION}

\section{Screening of $L A B$ and Yeast Strains from Kazakhstan Koumiss}

The previous literature revealed that LAB and yeast strains are 2 major microorganisms in traditional fermented foods (Tamang and Fleet, 2009; Lv et al., 2012; Tamang et al., 2016; García et al., 2019). Therefore, MRS and YPD agar plates were used to isolate LAB and yeast strains from Kazakhstan koumiss. All $52 \mathrm{LAB}$ isolates were gram-positive, mesophilic, nonspore-forming, catalase- and oxidase-negative, and rod-shaped, corresponding well with the classical characteristics of Lactobacillus given in Burgey's manual of Systematic Bacteriology (Forouhandeh et al., 2010). The 16S rRNA sequences were used as query sequences to BLAST in the GenBank DNA database (https:// blast.ncbi.nlm.nih.gov/Blast.cgi), and the sequences with 98 to $100 \%$ identities were selected for the phylogenetic analysis, and all the identified isolates are presented in Figure 1. These results were relatively consistent with Hao et al. (2010). Moreover, previous studies have observed the presence of these strains in traditional dairy products, including koumiss (Bilige et al., 2009). The microbial communities of koumiss are similar to those in kefir, cheese, and yogurt (Buttriss, 1997; Pan et al., 2011).

A total of 20 yeast clones were isolated on the YPD agar plate. We sequenced the $26 \mathrm{~S}$ rRNA genes from 20 isolates, and the similarity was checked by comparing the nucleotide sequence database NCBI in GenBank (https://blast.ncbi.nlm.nih.gov/Blast.cgi). We noted that the obtained sequences showed high similarity, ranging from 98 to $100 \%$ to reference sequences. The identified isolates are presented in Figure 2. It has been stated that yeasts are involved in the production of some fermented milk beverages in many countries around the world (Wang et al., 2008b). Yeast is one of the major components of the microbiota of various fermented milk and some other traditional milk products such as fermented milk of camel, goat, cow, and yak (Lore et al., 2005; Watanabe et al., 2008). Another study shows that yeast plays an important role in defining the qualitative traits of koumiss ( $\mathrm{Mu}$ et al., 2012). It has been investigated that the qualities of fermented milk may be mainly affected by the starter cultures because of its beneficial metabolites (such as some organic acids, exopolysaccharides, and flavor substances). For example, exopolysaccharides produced by some LAB could provide a better texture of yogurt and lower whey separation (Han et al., 2016). The LAB strains produce several compounds during lactic acid fermentations such as hydrogen peroxide, ethanol, organic compounds, exopolysaccharides, diacetyl, bacteriocins or bactericidal proteins, and other several enzymes. These compounds are important for various characteristics, such as color, flavor, and aroma, whereas LAB could control the functional characteristics that include fibrinolytic activity, probiotic effects, and antioxidant activity of fermented food (Kavitake et al., 2018; Rakhmanova et al., 2018). In addition, it was further postulated that LAB could affect the growth of filamentous fungi and yeasts that may alter the formation of wine flavor due to the esterification of ethanol and lactic acid or other acids produced by yeasts and filamentous fungi (Liu et al., 2003; Wang et al., 2008a).

\section{Combinations of the Selected LAB and Yeast Strains}

To further confirm which LAB strains are the most important bacteria species in Kazakhstan koumiss fermentation, sensory analysis of a single-bacteria fermented milk was conducted. Among all Lactobacillus strains, KZLAB13 strain was selected as the best and used for further investigation. The KZLAB13 strain is in the group with Lactobacillus delbrueckii ssp. delbrueckii DSM 20074 JCM 1012 reference strain and has $93 \%$ similarity. According to the results, the milk samples fermented by KZLAB13 strain showed good appearance and a pleasant odor after evaluating by welltrained panelists (Supplemental Table S1, https://doi .org/10.3168/jds.2020-18527). Similarly, L. delbrueckii ssp. bulgaricus is the key organism used as a starter for the preparation of yogurt and may play a major role in the coagulation of milk by rapidly increasing the acidity (Yu et al., 2011). Also, it has been reported that proteolytic strains of L. delbrueckii ssp. bulgaricus could hydrolyze proteins that may alter the viscosity and trigger the firmness of the yogurt samples (Shihata and Shah, 2002). Therefore, the KZLAB13 strain was selected for cofermentation with yeast strains isolated from koumiss. As for the selection of the best yeast strain, sensory evaluation of the sample was conducted after fermenting by each yeast strain combined with the KZLAB13 strain. The sensory score was remarkably higher for the KZLAB13 strain together with the KZY10 strain combination compared with other combinations (Supplementary Table S2, https://doi.org/ 10.3168/jds.2020-18527). The KZY10 strain is in the same group with Kluveromyces marxianus E4 reference strain and has $88 \%$ similarity. Interestingly, K. marxianus was also found to be the most prevalent species in Asian fermented milk, and it was a kind of thermotolerant yeast present in the kefir (Gethins et al., 2016). Some studies found that the cooperation of LAB and yeast is crucial for the production of acidified milk during fungal-lactic fermentations (Tamang et al., 2016). 
Kluveromyces marxianus has been considered as one of the most important starter cultures of fermentation due to its attractive organoleptic profile and rapid growth. Furthermore, K. marxianus is an acid tolerant species and can produce a lower level of ethanol. Therefore, $K$. marxianus species play an important role in food fermentation (Lane and Morrissey, 2010; Morrissey et al., 2015). Thus, KZLAB13 and KZY10 strains were selected as starter cultures for further analysis.

\section{One Factor at a Time Experimental Design}

The effect of fermentation parameters such as time, temperature, and inoculum size on the sensory evaluation of the fermented cow milk by the mixture of koumiss microorganisms such as KZLAB13 and KZY10 strains was investigated using a single-factor experiment (Figure 3). It indicated that fermentation time, fermentation temperature, and inoculum size of a start-

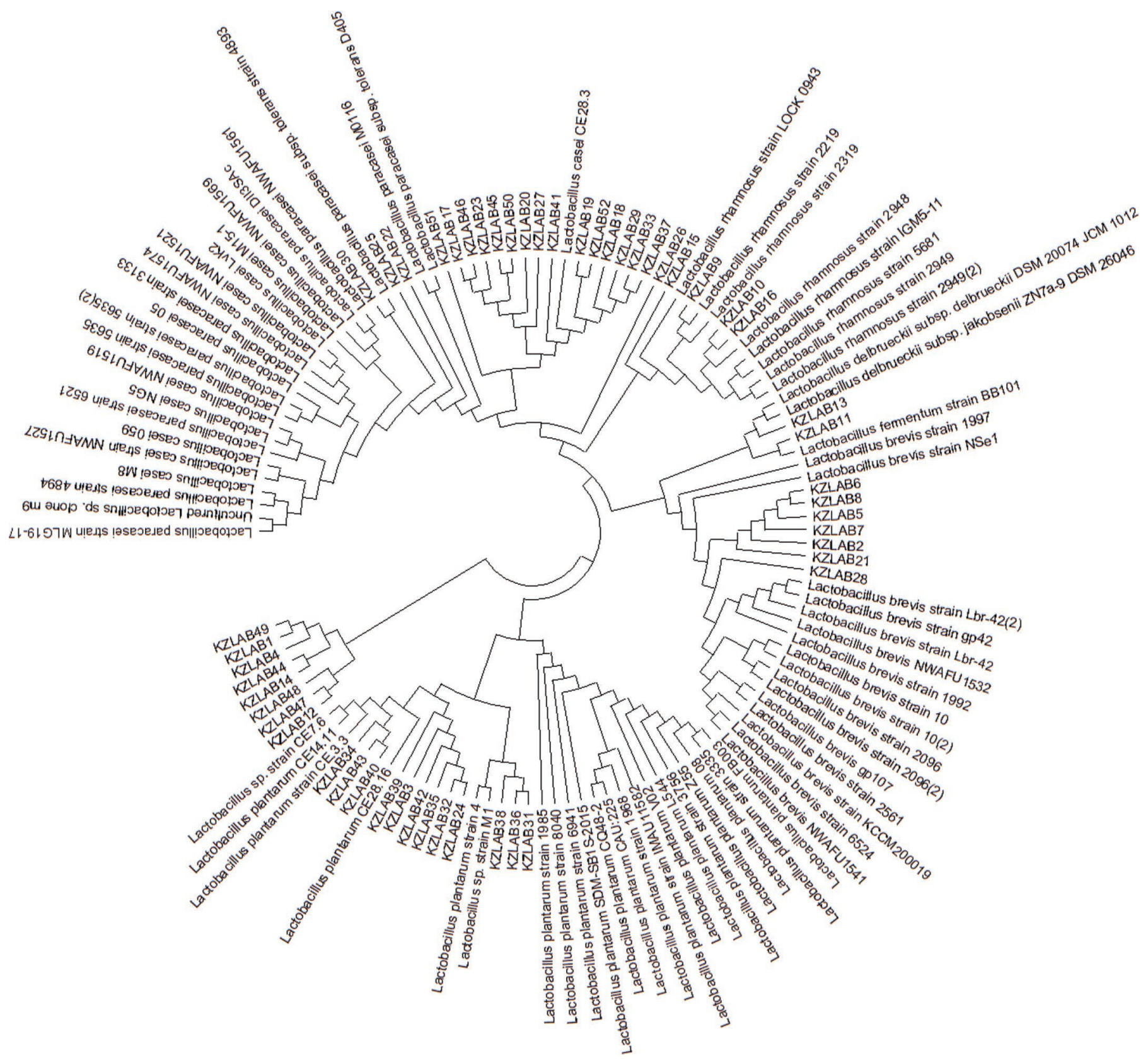

Figure 1. Phylogenetic tree based on $16 \mathrm{~S}$ rRNA sequences constructed by the maximum likelihood method. 
er culture greatly influenced the quality of cow-milk koumiss. The previous study found that the volatile compounds involved in the sensory characteristics were influenced by the inoculum size, which also significantly affects the overall fermentation results (Helland et al., 2004). We observed that the sensory evaluation scores were significantly increased with the prolonging of the fermentation time from 7 to $16 \mathrm{~h}$ for the fermented

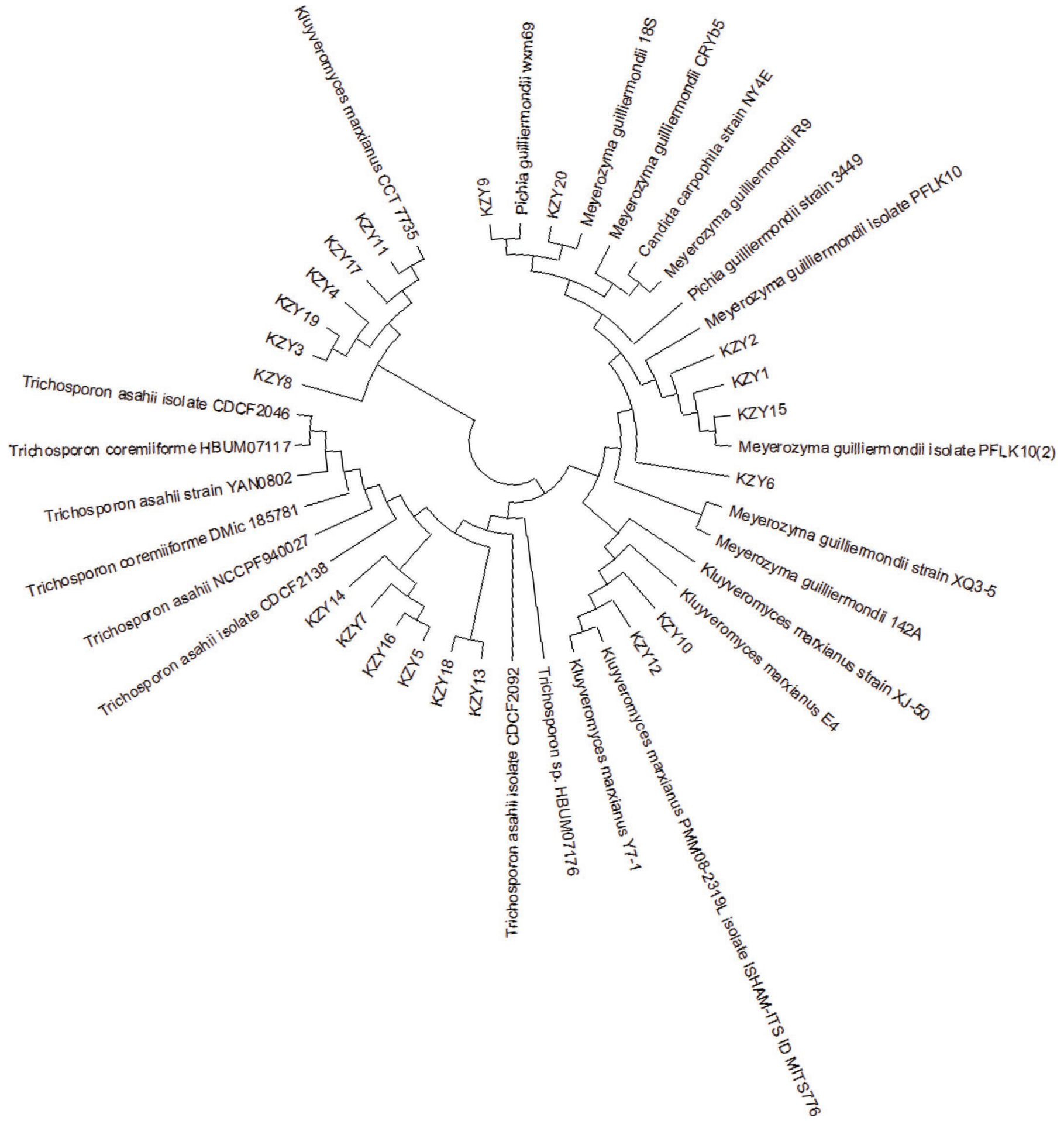

Figure 2. Phylogenetic tree based on $26 \mathrm{~S}$ rRNA sequences constructed by the maximum likelihood method. 
product; however, a reduction was noted at 19 and 21 $\mathrm{h}$ time points. Moreover, the highest sensory evaluation scores were detected at the $16 \mathrm{~h}$ time point, whereas the lowest sensory evaluation scores were found at 7 and $21 \mathrm{~h}$, respectively (Figure $3 \mathrm{~A}$ ). The highest sensory evaluation scores were observed at $16 \mathrm{~h}$, suggesting the optimum fermentation time for the fermented product. Furthermore, we studied the influence of fermentation temperature $\left(24,28,32,36,40\right.$, and $\left.44^{\circ} \mathrm{C}\right)$ on sensory evaluation of the cow-milk koumiss (Figure 3B). The results showed that fermentation temperatures significantly affected the sensory evaluation of the cow-milk koumiss. The gradual increase was noted for sensory evaluation of the cow-milk koumiss at 24, 28, and 32 ${ }^{\circ} \mathrm{C}$, and at $36^{\circ} \mathrm{C}$ cow-milk koumiss had the highest sensory evaluation score compared with other temperatures, whereas gradual decline was detected after $36^{\circ} \mathrm{C}$. At $36^{\circ} \mathrm{C}$, cow-milk koumiss showed the highest sensory score, indicating the optimum temperature for further optimization. Previously, it has been reported that fermentation temperature also plays an important role in the walnut milk beverage fermentation (Cui et al., 2013). Therefore, the optimum inoculum size of the starter culture was $4 \%$ (vol/vol) for every 100 $\mathrm{mL}$ of milk because of its highest sensory evaluation score discovered (Figure 3C). Recent studies postulated that sensory evaluation is directly proportional to the fermentation time. The fermentation time triggered the acidity of the fermented food (Wang et al., 2019). Moreover, it has been observed that the fermentation time significantly affects the rate of fermentation (Pereira et al., 2011; Cui et al., 2013).

\section{Response Surface Methodology to Optimize the Fermentation Parameters}

In the present study, an overall second polynomial equation by multiple regression analysis was developed for the sensory evaluation as represented below in terms of code values:

$$
\begin{aligned}
& Y=91.80+12.38 X_{1}+7 X_{2}+0.37 X_{3}-4 X_{1} X_{2}+ \\
& 4.25 X_{1} X_{3}-9 X_{2} X_{3}-16.78 X_{1}^{2}-10.03 X_{2}^{2}-22.27 X_{3}^{2}
\end{aligned}
$$

where $Y$ is the sensory evaluation, $X_{1}$ is inoculum size, $X_{2}$ is fermentation temperature, and $X_{3}$ is fermentation time, respectively.

In Table 3, the F-value (30.30) of the model indicates that the regression model was statistically significant $(P<0.01)$. The $\mathrm{R}^{2}(0.9750)$ and adjusted $\mathrm{R}^{2}(0.9428)$ suggested that the regression equation developed has a goodness of fit and could successfully predict the response and explain more than $95 \%$ of the variability in sensory evaluation. The $P$-value for lack of fit $(0.1033)$ implied the lack of fit was not significant compared with the pure error. Furthermore, the coefficient of variation $(6.92 \%)$ indicated a high degree of precision and better reliability of the experimental results. These results suggested that the model is reliable. The smaller the magnitude of the $P$-value, the more significant the corresponding term was. The most significant factors of this model were $X_{1}, X_{1}^{2}$, and $X_{3}^{2}$, with $P$-values less than 0.001 each; $X_{1}, X_{2}, X_{3}$, and $X_{2}^{2}$ are also significant. Information visualization of the relationship between variables and response were carried out through 3-dimensional response surfaces and count plots based on the result of the second-order polynomial function model (Figure 4). As shown in Figure 4A and 4D, inoculum size $\left(X_{1}\right)$ and temperature $\left(X_{2}\right)$ displayed a significant effect on the sensory evaluation of the cowmilk koumiss. This result suggests that inoculum size and fermentation temperature might be the crucial factors to improve the sensory evaluation of cow-milk koumiss. The mutual interaction between temperature
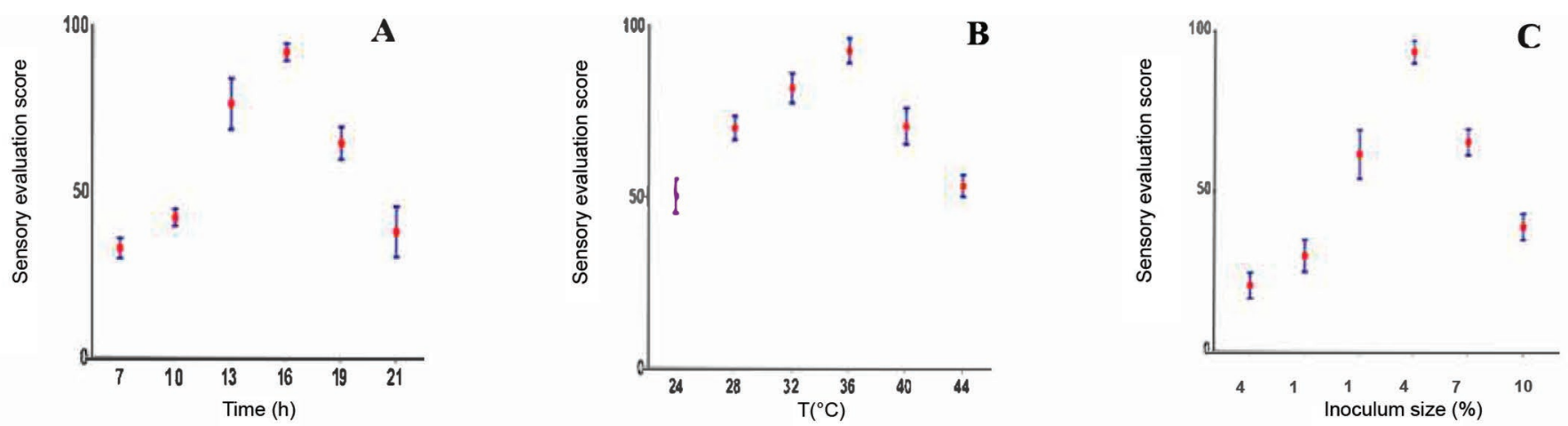

Figure 3. Effect of fermentation time (A), fermentation temperature (B), and inoculation size (C) on the sensory evaluation of the cow-milk koumiss. Data represent means $\pm \mathrm{SD}(\mathrm{n}=10$ for sensory evaluation scores). 
and time $\left(X_{3}\right)$ was significant, as the shape of the contour looks like an oval, which is consistent with the results of ANOVA analysis (Figure 4C). On the contrary, circular shapes in Figure 4A indicate that the synergistic effects of inoculum size and temperature were not apparent. Based on the regression equation, the optimal fermentation parameters for the maximum score of the sensory evaluation are the fermentation temperature at $36^{\circ} \mathrm{C}$, the inoculum size of starter culture at $4 \%$, and the fermentation time of $16 \mathrm{~h}$.

\section{Physicochemical Characteristics of Kazakhstan Koumiss and Cow-Milk Koumiss}

The average physicochemical and microbiological properties of Kazakhstan koumiss and cow-milk koumiss are shown in Table 4. All data compared with Kazakhstan koumiss and values of acidity, pH, ethanol, protein, yeasts, and LAB contents of cow-milk koumiss significantly varied from Kazakhstan koumiss. The $\mathrm{pH}$ and acidity of cow-milk koumiss were 4.3 and 71.6 degrees of titratable acidity, respectively. The cow-milk koumiss had a $\mathrm{pH}$ of $\sim 4.3$ due to lactic acid production, and another study found similar results for koumiss after inoculation with starter cultures at $25^{\circ} \mathrm{C}$ from modified bovine milk (Kücükcetin et al., 2003). The koumiss was classified in groups varying on their $\mathrm{pH}$. According to this classification of koumiss as strong ( $\mathrm{pH} 3.3-3.6$ ), moderate (3.9-4.5), and light (4.5-5.0), cow-milk koumiss can be fitted to the moderate koumiss group. The titratable acidity of the Kazakhstan koumiss sample is slightly higher compared with those in the cow-milk koumiss. Our result is in line with the findings reported by Chen et al. (2010) and Ishii et al. (2014). Based on the previous literature, we observed that several factors affected the acidification parameters. This may be because of the differences in raw material and fermentation procedure. Cow-milk koumiss had higher protein content than the Kazakhstan koumiss. It was noted that the protein contents were 1.9 and $2.7 \%$ for Kazakhstan koumiss and cow milk koumiss, respectively, similar to the previous findings by $\mathrm{Ha}$ et al. (2003). Another study also revealed that protein content depends on the milk source; for example, the protein level in cow milk is higher than mare milk, whereas the ratio of casein to whey protein $(1: 1)$ is quite similar to human milk (Ha et al., 2003). The number of microorganisms in Kazakhstan koumiss was $2.24 \times 10^{8}(\mathrm{cfu} / \mathrm{mL})$ of LAB and $2.41 \times 10^{6}(\mathrm{cfu} / \mathrm{mL})$ of yeast, and in the cow-milk koumiss, $9.9 \times 10^{6}(\mathrm{cfu} / \mathrm{mL})$ of LAB and $1.14 \times 10^{6}$ $(\mathrm{cfu} / \mathrm{mL})$ of yeast, showing that in Kazakhstan koumiss $\mathrm{LAB}$ and yeasts accounted for a high ratio.

\section{Quantification of the VOC}

Traditional koumiss is known to contain a large number of LAB and yeast strains. Previous researchers identified more than 50 LAB strains from koumiss (Bai and Ji, 2017). Such microbiological biodiversity due to spontaneous fermentation could explain the high number of potential volatile compounds in typical beverages compared with our samples obtained after the optimized fermentation of cow milk by the koumiss starter culture. Table 5 shows the VOC, whose quantity and presence significantly differ from the reference Kazakhstan koumiss sample. Their mean abundance and concentration were quantified, and a total of $41 \mathrm{VOC}$ were detected in the present study. One of the most important compounds for koumiss is ethanol. Compared with Kazakhstan koumiss, which contained $22.98 \mu \mathrm{g} / \mathrm{L}$ of ethanol, our samples of the cow-milk koumiss had a low quantity of alcohol. Indeed, the high level of ethanol usually found in traditional koumiss is usually due to yeast (Gadaga et al., 2007). However, our cow-milk koumiss contained ethanol at a concentration of 20.83 $\mu \mathrm{g} / \mathrm{L}$. This could be due to certain strains of bacteria and because, as mentioned before, K. marxianus produces less alcohol. Additionally, ethanol production could be possible in relatively high quantities with Lactobacillus strains (Pan et al., 2014). It is also explained by the fact that mare milk has more sugar than cow milk, and during the fermentation process, sugar converts to alcohol by the starter culture. Some reports investigated that 3-methylbutanoic acid and its corresponding alcohols and aldehydes, namely 3-methylbutanol and 3-methylbutanal, are AA degradation products. It has been identified that the oxidation of 3-methylbutanal can produce 3-methylbutanoic acid (Smit et al., 2009). In dairy foods, the quantity of 3-methylbutanol is considerably high and imparts an "alcoholic and floral" flavor to fermented milk (Molimard and Spinnler, 1996). The value for 3-methylbutanoic acid was $0.32 \mu \mathrm{g} / \mathrm{L}$, suggesting that the oxidation of 3-methylbutanal may lead the production of 3-methylbutanoic acid in koumiss samples. The results of our study found a maximum value of 4.7 and $1.25 \mu \mathrm{g} / \mathrm{L}$ for 3-methylbutanol in Kazakhstan koumiss and cow-milk koumiss, respectively. The use of cow milk as a matrix for inoculation could also explain that only 19 compounds from Kazakhstan koumiss were common with the VOC in cow milk koumiss. Certainly, there is an important difference in lactose content between mare milk $(60-80 \mathrm{~g} / \mathrm{L})$ and cow milk (30-50 g/L); consequently, LAB strains could produce a higher compound variability. The most discriminating molecule oxime methoxy-phenyl (OMP) is a chemical product belonging to the imine group, which 


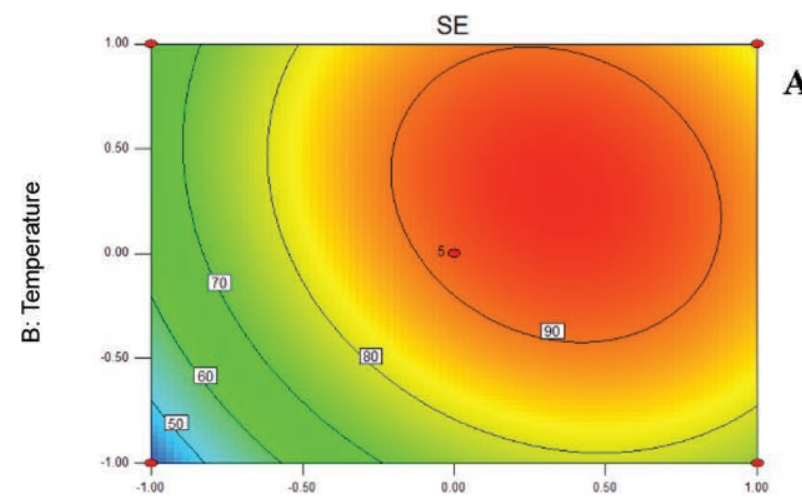

A: Inoculum size
A

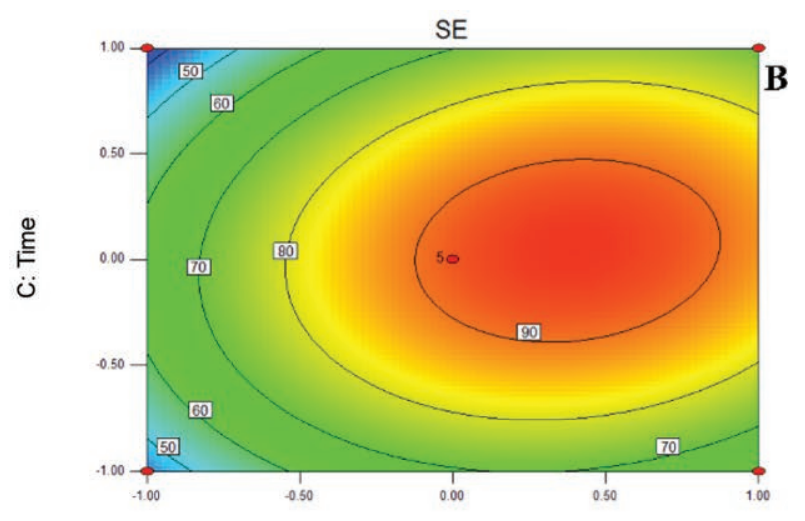

A: Inoculum size

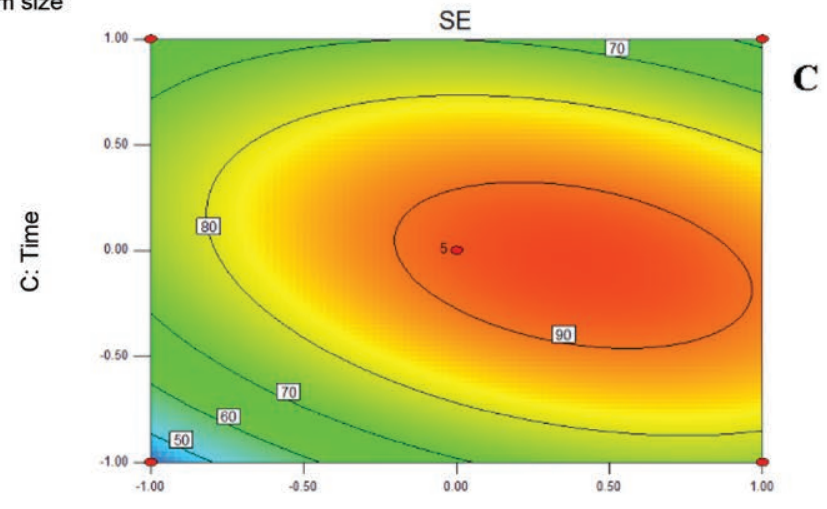

B: Temperature

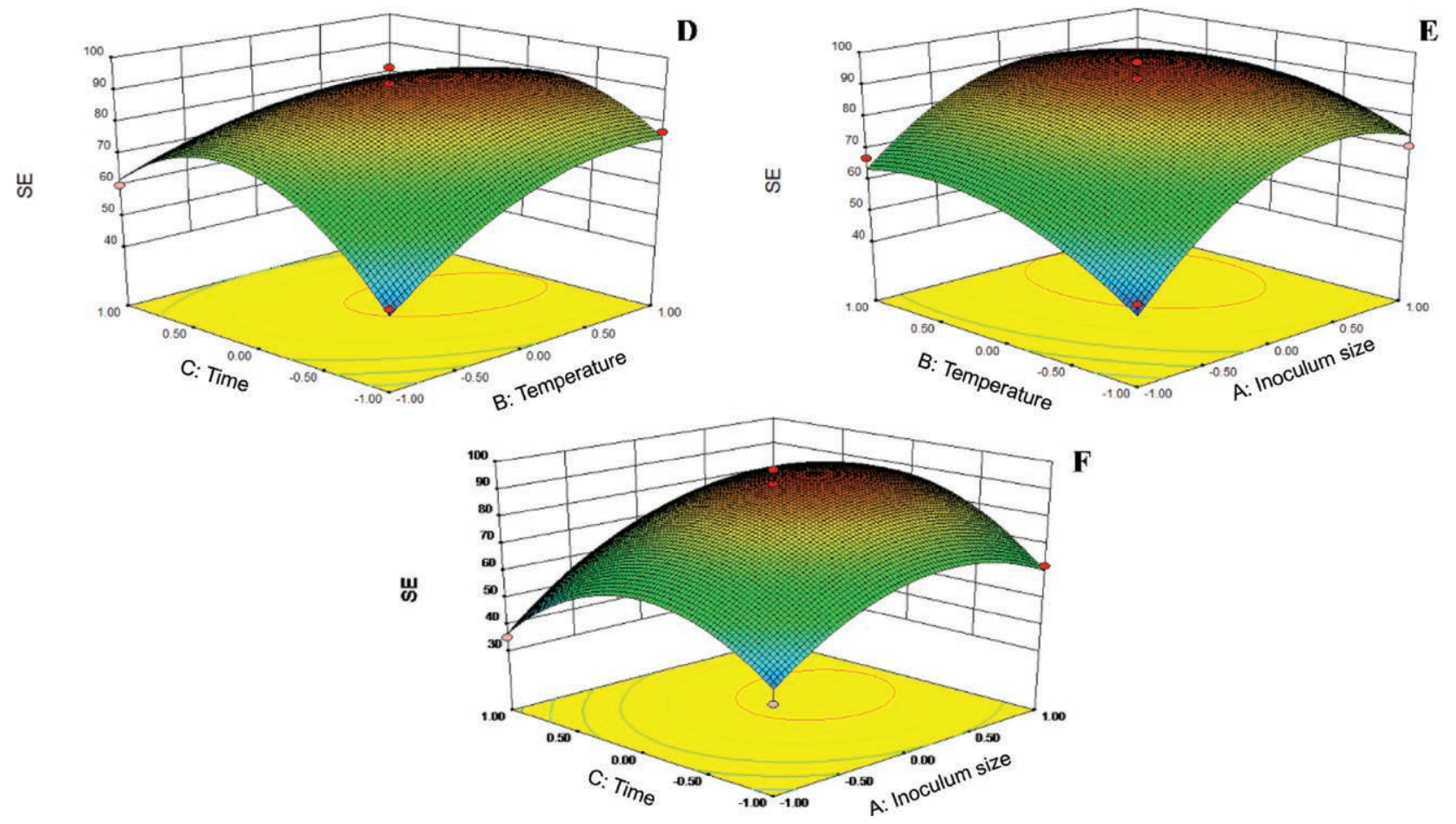

Figure 4. Normal plots and 3-dimensional surface plots indicating the interaction effects of independent variables on sensory evaluation. Journal of Dairy Science Vol. 104 No. 1, 2021 


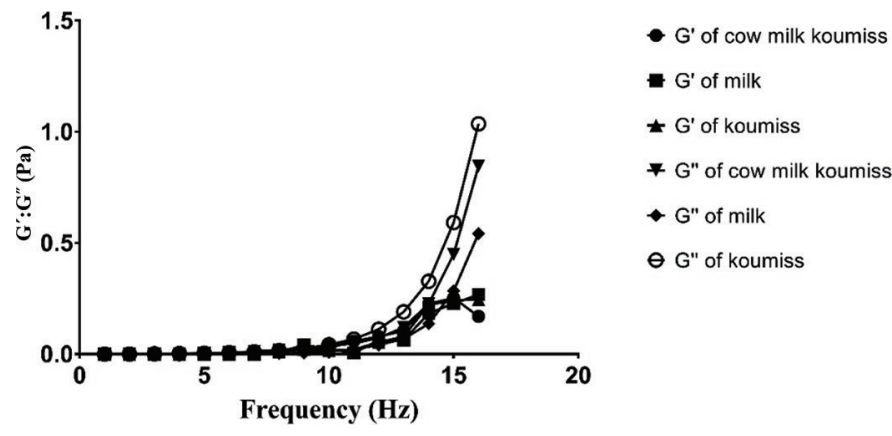

Figure 5. Frequency sweeps of Kazakhstan koumiss, cow-milk koumiss, and milk at $1 \%$ strain. $\mathrm{G}^{\prime}=$ storage modulus; $\mathrm{G}^{\prime \prime}=$ loss modulus

has sweetener taste. Generally, OMP is present in large quantities in UHT cow milk (Dursun et al., 2017). In the present study, OMP was significantly higher $(P<$ $0.01)$ in the milk sample than compared with Kazakhstan koumiss and cow-milk koumiss. It was observed that acetaldehyde is critical for the aroma of yogurt type milk, and thus acetaldehyde has received more attention among all secondary metabolites (Beshkova et al., 2003). Herein, we detected that the acetaldehyde contents were higher in the cow-milk koumiss. This higher concentration may be due to a component of the starter isolated from Kazakhstan koumiss, known as KZLAB13 strain. The previous study observed that compared with other LAB, L. delbrueckii strain shared markedly high acetaldehyde production activity in the kefir starter (Simova et al., 2002). We identified a total of 11 acid compounds among the studied samples. The most abundant acidic compound was acetic acid, followed by octanic acid and butanic acid, respectively. It was reported that acetic acid is the major subproduct of LAB fermentation (Smit et al., 2009). The range of

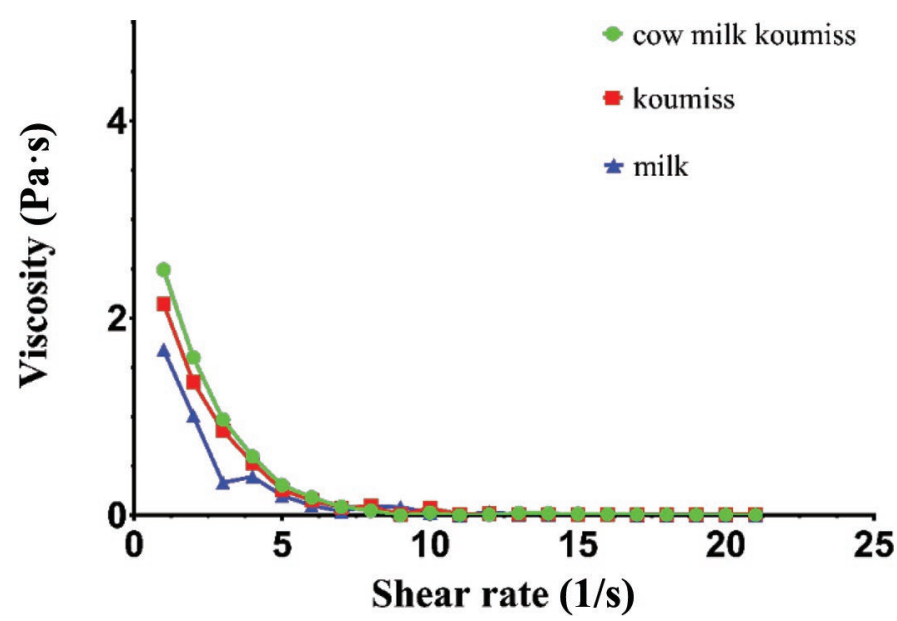

Figure 6. The flow behavior of samples. acetic acid concentration was 0.33 to $2.87 \mu \mathrm{g} / \mathrm{L}$, where the highest value was detected for Kazakhstan koumiss samples. Furthermore, the butanoic acid and octanoic acid concentrations were only observed for Kazakhstan koumiss samples. Previous studies found that these important acid compounds are found abundantly in dairy foods as well as in fermented milk (Pan et al., 2014). It was also hypothesized that volatile compounds may affect the sensory characteristics including flavor and taste in fermented milk products (Cheng, 2010). We noted that the value of hexanal concentration reached up to $0.024 \mu \mathrm{g} / \mathrm{L}$ in the Kazakhstan koumiss, whereas this value was $0.22 \mu \mathrm{g} / \mathrm{L}$ in cow-milk koumiss, which is significantly lower compared with Kazakhstan koumiss samples. In line with above, recent studies showed that hexanal is an important compound for flavor that can be produced by the oxidation of unsaturated fatty acids in dairy products such as fermented milk (Liang et al., 2012). A total of 6 ketone compounds were detected in the Kazakhstan koumiss, cow-milk koumiss, and milk samples. Among them, some are essential flavor VOC such as 2-heptanone and 9-octadecanone, which were present in considerably high amounts in the studied samples. The concentration of these compounds was 0.3 $\mu \mathrm{g} / \mathrm{L}$, which was higher than compared with cow-milk koumiss.

\section{Rheological Properties}

According to the previous studies, the apparent viscosity is considered to be the function of the shear rate, and both (apparent viscosity and shear rate) are inversely proportional to each other. The increase in the shear rate decreases the apparent viscosity, suggesting the pseudoplastic pattern for all the fermented products (Campanella et al., 1995; Abu-Jdayil and Mohameed, 2002). We observed that the apparent viscosity of cowmilk koumiss was higher than the Kazakhstan koumiss at the beginning of shearing. The casein to whey protein ratio and casein concentration were lower in the mare milk as compared with the cow milk. Furthermore, we noticed clear differences in the casein fractions and the size of casein micelles between mare milk and cow milk. According to earlier studies, the casein of mare milk possesses an equal amount of $\beta$ - and $\alpha_{S^{-}}$casein, while $\alpha_{S}$-casein concentration is slightly higher than $\beta$-casein concentration in cow milk (Ochirkhuyag et al., 2000; Malacarne et al., 2002). It was further investigated that the concentration of $\kappa$-casein is higher in mare milk as compared with cow milk (Egito et al., 2001). The casein micelles of mare milk are larger and less porous than cow milk (Buchheim et al., 1989). These distinguishing properties of cow and mare-milk casein may play an important role in the differentiation of rheo- 
logical properties of the mare and cow milk. A similar pattern for casein between cow and mare milk was also reported in the present study. The frequency dependence of storage modulus $\left(\mathrm{G}^{\prime}\right)$ and loss modulus $\left(\mathrm{G}^{\prime \prime}\right)$ was determined by using frequency sweeps at $1 \%$ strain (Figure 5). We observed that the apparent viscosity of cow milk koumiss was higher than the Kazakhstan koumiss at the beginning of shearing (Figure 6). The dynamic testing provides useful information on the viscoelastic properties of yogurts (i.e., the $\mathrm{G}^{\prime}$ and $\mathrm{G}^{\prime \prime}$ ), which denote the degree of elastic and viscous behavior, respectively. For all samples, the response was typical for yogurt gels with $\mathrm{G}^{\prime}$ higher than $\mathrm{G}^{\prime \prime}$.

\section{CONCLUSIONS}

The present study indicates that cow-milk koumiss fermented by a combination of KZLAB13 and KZY10 strains isolated from the traditional homemade Kazakhstan koumiss possessed a satisfactory taste, flavor, and physicochemical and rheological properties. Further, it suggests that this cofermented cow-milk koumiss can be considered as a good alternative product for koumiss by breaking the resource limitation and reducing the material cost. Nevertheless, scale-up fermentation should also be carried out in future studies to support their industrial production. In addition, evaluation of the beneficial health effects of this fermented cow-milk koumiss is of significance to enhance its acceptability among different groups of people.

\section{ACKNOWLEDGMENTS}

No funding was received for the work. We thank Zaid Ashiq Khan (Northwest A \& F University, Yangling, China) for his kind assistance concerning manuscript language improvement. We also acknowledge the suggestions and constructive comments from the editor and the anonymous reviewers. All authors declare that there is no conflict of interest. Laboratory experiments and methodology were performed by A. R., T. W., W. X., and A. R., and G.X. did formal analysis and software. A. R. wrote the original draft. Review and editing were performed by L. M., Y. H., Y. L., L. X., and Q. Z.. Supervision was performed by X. L..

\section{REFERENCES}

Abu-Jdayil, B., and H. Mohameed. 2002. Experimental and modelling studies of the flow properties of concentrated yogurt as affected by the storage time. J. Food Eng. 52:359-365. https://doi.org/10 .1016/S0260-8774(01)00127-3.

Bai, L., and S. Ji. 2017. Isolation and identification of lactic acid bacteria from koumiss in Eastern Inner Mongolia of China. In Proc. International Conference on Materials Science, Resource and En- vironmental Engineering, Xi'an City, Shaanxi, China. AIP Conference Proceedings 1794:050005. https://doi.org/10.1063/1.4971951.

Beshkova, D., E. Simova, G. Frengova, Z. Simov, and Z. P. Dimitrov. 2003. Production of volatile aroma compounds by kefir starter cultures. Int. Dairy J. 13:529-535. https://doi.org/10.1016/S0958 -6946(03)00058-X.

Bilige, M., W. Liu, W. Rina, L. Wang, T. Sun, J. Wang, H. Li, and H. Zhang. 2009. Evaluation of potential probiotics properties of the screened Lactobacilli isolated from home-made koumiss in Mongolia. Ann. Microbiol. 59:493-498. https://doi.org/10.1007/ BF03175136.

Bornaz, S., N. Guizani, J. Sammari, W. Allouch, A. Sahli, and H. Attia. 2010. Physicochemical properties of fermented Arabian mares' milk. Int. Dairy J. 20:500-505. https://doi.org/10.1016/j.idairyj .2010.02.001.

Buchheim, W., S. Lund, and J. Scholtissek. 1989. Vergleichende Untersuchungen zur Struktur und Grösse von Caseinmicellen in der Milch verschiedener Species. Kieler Milchwirtschaftliche Forschungsberichte 41:253-265.

Buttriss, J. 1997. Nutritional properties of fermented milk products. Int. J. Dairy Technol. 50:21-27. https://doi.org/10.1111/j.1471 -0307.1997.tb01731.x.

Cagno, R. D., A. Tamborrino, G. Gallo, C. Leone, M. D. Angelis, M. Faccia, P. Amirante, and M. Gobbetti. 2004. Uses of mares' milk in manufacture of fermented milks. Int. Dairy J. 14:767-775. https: //doi.org/10.1016/j.idairyj.2004.02.005.

Campanella, O., N. Dorward, and H. Singh. 1995. A study of the rheological properties of concentrated food emulsions. J. Food Eng. 25:427-440. https://doi.org/10.1016/0260-8774(94)00000-Y.

Chen, Y., Z. Wang, X. Chen, Y. Liu, H. Zhang, and T. Sun. 2010. Identification of angiotensin I-converting enzyme inhibitory peptides from koumiss, a traditional fermented mare's milk. J. Dairy Sci. 93:884-892. https://doi.org/10.3168/jds.2009-2672.

Cheng, H. 2010. Volatile flavor compounds in yogurt: A review. Crit. Rev. Food Sci. Nutr. 50:938-950. https://doi.org/10.1080/ 10408390903044081.

Cheng, Y., H. Wei, R. Sun, Z. Tian, and X. Zheng. 2016. Rapid method for protein quantitation by Bradford assay after elimination of the interference of polysorbate 80. Anal. Biochem. 494:37-39. https://doi.org/10.1016/j.ab.2015.10.013.

Cui, X.-H., S.-J. Chen, Y. Wang, and J.-R. Han. 2013. Fermentation conditions of walnut milk beverage inoculated with kefir grains. Lebensm. Wiss. Technol. 50:349-352. https://doi.org/10.1016/j .lwt.2012.07.043.

Dan, T., H. Chen, T. Li, J. Tian, W. Ren, H. Zhang, and T. Sun. 2019. Influence of Lactobacillus plantarum P-8 on fermented milk flavor and storage stability. Front. Microbiol. 9:3133-3146. https://doi .org/10.3389/fmicb.2018.03133.

Dan, T., D. Wang, R. Jin, H. Zhang, T. Zhou, and T. Sun. 2017. Characterization of volatile compounds in fermented milk using solidphase microextraction methods coupled with gas chromatographymass spectrometry. J. Dairy Sci. 100:2488-2500. https://doi.org/ 10.3168/jds.2016-11528.

Danova, S., K. Petrov, P. Pavlov, and P. Petrova. 2005. Isolation and characterization of Lactobacillus strains involved in koumiss fermentation. Int. J. Dairy Technol. 58:100-105. https://doi.org/10 .1111/j.1471-0307.2005.00194.x.

Dertli, E., E. Mercan, M. Arıcı, M. T. Yılmaz, and O. Sağdıç. 2016. Characterisation of lactic acid bacteria from Turkish sourdough and determination of their exopolysaccharide (EPS) production characteristics. Lebensm. Wiss. Technol. 71:116-124. https://doi .org/10.1016/j.lwt.2016.03.030.

Dhewa, T., V. Mishra, N. Kumar, and K. Sangu. 2015. Koumiss: The nutritional and therapeutic values. Pages 483-494 in Fermented Fermented Milk and Dairy Products. CRC Press, Boca Raton, FL.

Dönmez, N., İ. Kısadere, C. Balaban, and N. Kadiralieva. 2014. Effects of traditional homemade koumiss on some hematological and biochemical characteristics in sedentary men exposed to exercise. Biotech. Histochem. 89:558-563. https://doi.org/10.3109/10520295 .2014.915428. 
Doreau, M. and W. Martin-Rosset. 2011. Animals that produce dairy foods Horse. Pages 358-364 in Encyclopedia of Dairy Sciences, second ed. Academic Press, Cambridge, MA.

Dursun, A., Z. Güler, and Y. E. Şekerli. 2017. Characterization of volatile compounds and organic acids in ultra-high-temperature milk packaged in tetra brik cartons. Int. J. Food Prop. 20:1511-1521. https://doi.org/10.1080/10942912.2016.1213280.

Egito, A., J.-M. Girardet, L. Miclo, D. Mollé, G. Humbert, and J.-L. Gaillard. 2001. Susceptibility of equine $\kappa$-and $\beta$-caseins to hydrolysis by chymosin. Int. Dairy J. 11:885-893. https://doi.org/10 .1016/S0958-6946(01)00123-6.

Forouhandeh, H., A. Vahed, M. Hejazi, M. Nahaei, and M. A. Dibavar. 2010. Isolation and phenotypic characterization of Lactobacillus species from various dairy products. Curr. Res. Bacteriol. 3:84-88. https://doi.org/10.3923/crb.2010.84.88.

Gadaga, T. H., B. C. Viljoen, and J. A. Narvhus. 2007. Volatile organic compounds in naturally fermented milk and milk fermented using yeasts, lactic acid bacteria and their combinations as starter cultures. Food Technol. Biotechnol. 45:195-200.

García, C., M. Rendueles, and M. Díaz. 2019. Liquid-phase food fermentations with microbial consortia involving lactic acid bacteria. Food Res. Int. 119:207-220. https://doi.org/10.1016/j.foodres 2019.01.043.

Gethins, L., M. C. Rea, C. Stanton, R. P. Ross, K. Kilcawley, M. O'Sullivan, S. Crotty, and J. P. Morrissey. 2016. Acquisition of the yeast Kluyveromyces marxianus from unpasteurised milk by a kefir grain enhances kefir quality. FEMS Microbiol. Lett. 363:fnw165. https://doi.org/10.1093/femsle/fnw165.

Ha, S., A. Leng, and L. Mang. 2003. Koumiss and its medicinal values. China Journal of Chinese Materia. Medica. 28:11-14.

Han, X., Z. Yang, X. Jing, P. Yu, Y. Zhang, H. Yi, and L. Zhang. 2016. Improvement of the texture of yogurt by use of exopolysaccharide producing lactic acid bacteria. BioMed Res. Int. 2016:7945675. https://doi.org/10.1155/2016/7945675.

Hao, Y., L. Zhao, H. Zhang, Z. Zhai, Y. Huang, X. Liu, and L. Zhang. 2010. Identification of the bacterial biodiversity in koumiss by denaturing gradient gel electrophoresis and species-specific polymerase chain reaction. J. Dairy Sci. 93:1926-1933. https://doi.org/ 10.3168/jds.2009-2822.

Helland, M. H., T. Wicklund, and J. A. Narvhus. 2004. Growth and metabolism of selected strains of probiotic bacteria, in maize porridge with added malted barley. Int. J. Food Microbiol. 91:305313. https://doi.org/10.1016/j.ijfoodmicro.2003.07.007.

Hui, Y. H., and E. Ö. Evranuz. 2012. Handbook of animal-based fermented food and beverage technology. Vol. 1. CRC press, Boca Raton, FL.

Ishii, S., B. Hosino, H. Komiyama, A. Uehara, and S. Nurtazin. 2014. Study on production and properties of kumiss of herders in Mongolian dry steppe. J. of Arid Land Stud. 24:196-197.

Kavitake, D., S. Kandasamy, P. B. Devi, and P. H. Shetty. 2018. Recent developments on encapsulation of lactic acid bacteria as potential starter culture in fermented foods-A review. Food Biosci. 21:34-44. https://doi.org/10.1016/j.fbio.2017.11.003.

Kücükcetin, A., H. Yaygin, J. Hinrichs, and U. Kulozik. 2003. Adaptation of bovine milk towards mares' milk composition by means of membrane technology for koumiss manufacture. Int. Dairy J. 13:945-951. https://doi.org/10.1016/S0958-6946(03)00143-2.

Lane, M. M., and J. P. Morrissey. 2010. Kluyveromyces marxianus: A yeast emerging from its sister's shadow. Fungal Biol. Rev. 24:1726. https://doi.org/10.1016/j.fbr.2010.01.001.

Langlois, B. 2011. The history, ethnology and social importance of mare's milk consumption in central Asia. J. Life Sci. 5:863-872.

Liang, H., S. Yang, W. Liu, and L. Yuan. 2012. In situ real-time monitoring of volatile metabolites of fermented milk by dynamic headspace sampling-atmospheric pressure ionization mass spectrometry. Shipin Kexue 33:307-310.

Liu, S.-Q., R. Holland, and V. Crow. 2003. Synthesis of ethyl butanoate by a commercial lipase in aqueous media under conditions relevant to cheese ripening. J. Dairy Res. 70:359-363. https://doi .org/10.1017/S0022029903006290.
Lore, T. A., S. K. Mbugua, and J. Wangoh. 2005. Enumeration and identification of microflora in suusac, a Kenyan traditional fermented camel milk product. Lebensm. Wiss. Technol. 38:125-130. https://doi.org/10.1016/j.lwt.2004.05.008.

Lv, X.-C., X. Weng, W. Zhang, P.-F. Rao, and L. Ni. 2012. Microbial diversity of traditional fermentation starters for Hong Qu glutinous rice wine as determined by PCR-mediated DGGE. Food Control 28:426-434. https://doi.org/10.1016/j.foodcont.2012.05.025.

Macciola, V., G. Candela, and A. De Leonardis. 2008. Rapid gaschromatographic method for the determination of diacetyl in milk, fermented milk and butter. Food Control 19:873-878. https://doi .org/10.1016/j.foodcont.2007.08.014.

Makimura, K., S. Y. Murayama, and H. Yamaguchi. 1994. Detection of a wide range of medically important fungi by the polymerase chain reaction. J. Med. Microbiol. 40:358-364. https://doi.org/10 $.1099 / 00222615-40-5-358$.

Malacarne, M., F. Martuzzi, A. Summer, and P. Mariani. 2002. Protein and fat composition of mare's milk: Some nutritional remarks with reference to human and cow's milk. Int. Dairy J. 12:869-877. https://doi.org/10.1016/S0958-6946(02)00120-6.

Molimard, P., and H. Spinnler. 1996. Compounds involved in the flavor of surface mold-ripened cheeses: Origins and properties. J. Dairy Sci. 79:169-184. https://doi.org/10.3168/jds.S0022-0302(96)76348 -8 .

Montanari, G., C. Zambonelli, L. Grazia, G. K. Kamesheva, and M. K. Shigaeva. 1996. Saccharomyces unisporus as the principal alcoholic fermentation microorganism of traditional koumiss. J. Dairy Res. 63:327-331. https://doi.org/10.1017/S0022029900031836.

Morrissey, J. P., M. M. Etschmann, J. Schrader, and G. M. de Billerbeck. 2015. Cell factory applications of the yeast Kluyveromyces marxianus for the biotechnological production of natural flavour and fragrance molecules. Yeast 32:3-16. https://doi.org/10.1002/ yea.3054.

Mu, Z., X. Yang, and H. Yuan. 2012. Detection and identification of wild yeast in Koumiss. Food Microbiol. 31:301-308. https://doi .org/10.1016/j.fm.2012.04.004.

Nair, P. S., and P. K. Surendran. 2005. Biochemical characterization of lactic acid bacteria isolated from fish and prawn. J. Culture. Collection. 4:48-52

Norris, J., R. Berkeley, N. Logan, and A. O'donnell. 1981. The genera Bacillus and Sporolactobacillus. Pages 1711-1742 in The Prokaryotes: A Handbook on Habitats, Isolation, and Identification of Bacteria, vol 2. M. P. Starr, H. Stolp, H. G. Truper, ed. SpringerVerlag, New York, NY.

Ochirkhuyag, B., J.-M. Chobert, M. Dalgalarrondo, and T. Haertlé. 2000. Characterization of mare caseins. Identification of $\alpha_{S_{1}-}$ and $\alpha_{S 2}$-caseins. Lait 80:223-235. https://doi.org/10.1051/lait:2000121.

Pan, D. D., Z. Wu, T. Peng, X. Zeng, and H. Li. 2014. Volatile organic compounds profile during milk fermentation by Lactobacillus pentosus and correlations between volatiles flavor and carbohydrate metabolism. J. Dairy Sci. 97:624-631. https://doi.org/10.3168/jds 2013-7131.

Pan, D. D., X. Q. Zeng, and Y. T. Yan. 2011. Characterisation of Lactobacillus fermentum SM-7 isolated from koumiss, a potential probiotic bacterium with cholesterol-lowering effects. J. Sci. Food Agric. 91:512-518. https://doi.org/10.1002/jsfa.4214.

Papadopoulou, O. S., A. A. Argyri, E. Varzakis, M. Sidira, Y. Kourkoutas, A. Galanis, C. Tassou, and N. G. Chorianopoulos. 2019 Use of lactobacilli strains with probiotic potential in traditional fermented milk and their impact on quality and safety related to Listeria monocytogenes. Int. Dairy J. 98:44-53. https://doi.org/10 .1016/j.idairyj.2019.06.006.

Park, Y. W., G. F. Haenlein, and W. L. Wendorff. 2006a. Page 512 in Handbook of Milk of Non-Bovine Mammals. W. Y. Park and G. F. W. Haenlein, ed. Blackwell Publishing, Oxford, UK.

Park, Y. W., H. Zhang, B. Zhang, and L. Zhang. 2006b. Mare milk. Pages 275-296 in Handbook of Milk of Nonbovine Mammals. W. Y. Park and G. F. W. Haenlein, ed. Blackwell Publishing, Oxford, UK.

Pereira, A. L. F., T. C. Maciel, and S. Rodrigues. 2011. Probiotic beverage from cashew apple juice fermented with Lactobacillus casei. 
Food Res. Int. 44:1276-1283. https://doi.org/10.1016/j.foodres .2010.11.035.

Rakhmanova, A., Z. Khan, and K. Shah. 2018. A mini review fermentation and preservation: Role of Lactic Acid Bacteria. Food Process Technol. 6:414-417. https://doi.org/10.15406/mojfpt.2018 .06 .00197 .

Saitou, N., and M. Nei. 1987. The neighbor-joining method: A new method for reconstructing phylogenetic trees. Mol. Biol. Evol. 4:406-425.

Salimei, E., and Y. W. Park. 2017. Mare milk. Pages 369-375 in Handbook of Milk of Non-Bovine Mammals. W.Y. Park and G. F. W. Haenlein, ed. Blackwell Publishing, Oxford, UK.

Shihata, A., and N. Shah. 2002. Influence of addition of proteolytic strains of Lactobacillus delbrueckii ssp. bulgaricus to commercial ABT starter cultures on texture of yoghurt, exopolysaccharide production and survival of bacteria. Int. Dairy J. 12:765-772. https://doi.org/10.1016/S0958-6946(02)00071-7.

Simova, E., D. Beshkova, A. Angelov, T. Hristozova, G. Frengova, and Z. Spasov. 2002. Lactic acid bacteria and yeasts in kefir grains and kefir made from them. J. Ind. Microbiol. Biotechnol. 28:1-6. https: //doi.org/10.1038/sj/jim/7000186.

Smit, B. A., W. J. Engels, and G. Smit. 2009. Branched chain aldehydes: Production and breakdown pathways and relevance for flavour in foods. Appl. Microbiol. Biotechnol. 81:987-999. https:// doi.org/10.1007/s00253-008-1758-x.

Tamang, J. P., and G. H. Fleet. 2009. Yeasts diversity in fermented foods and beverages. Pages 169-198 in Yeast Biotechnology: Diversity and Applications. Springer, New York, NY.

Tamang, J. P., K. Watanabe, and W. H. Holzapfel. 2016. Diversity of microorganisms in global fermented foods and beverages. Front. Microbiol. 7:377. https://doi.org/10.3389/fmicb.2016.00377.

Tamura, K., D. Peterson, N. Peterson, G. Stecher, M. Nei, and S. Kumar. 2011. MEGA5: Molecular evolutionary genetics analysis using maximum likelihood, evolutionary distance, and maximum parsimony methods. Mol. Biol. Evol. 28:2731-2739. https://doi .org $/ 10.1093 / \mathrm{molbev} / \mathrm{msr} 121$.

Wang, C., D. Shi, and G. Gong. 2008a. Microorganisms in Daqu: A starter culture of Chinese Maotai-flavor liquor. World J. Microbiol. Biotechnol. 24:2183-2190. https://doi.org/10.1007/s11274 -008-9728-0.

Wang, Q., C. Liu, Y. Jing, S. Fan, and J. Cai. 2019. Evaluation of fermentation conditions to improve the sensory quality of broomcorn millet sour porridge. Lebensm. Wiss. Technol. 104:165-172. https: //doi.org/10.1016/j.lwt.2019.01.037.

Wang, S.-Y.. H.-C. Chen, J.-R. Liu, Y.-C. Lin, and M.-J. Chen. 2008b. Identification of yeasts and evaluation of their distribution in Taiwanese kefir and viili starters. J. Dairy Sci. 91:3798-3805. https:/ /doi.org/10.3168/jds.2007-0468.

Wang, X., Q. Chen, and X. Lü. 2014. Pectin extracted from apple pomace and citrus peel by subcritical water. Food Hydrocoll. 38:129-137. https://doi.org/10.1016/j.foodhyd.2013.12.003.

Watanabe, K., J. Fujimoto, M. Sasamoto, J. Dugersuren, T. Tumursuh, and S. Demberel. 2008. Diversity of lactic acid bacteria and yeasts in Airag and Tarag, traditional fermented milk products of Mongolia. World J. Microbiol. Biotechnol. 24:1313-1325. https:// doi.org/10.1007/s11274-007-9604-3.

Yu, J., W. Wang, B. Menghe, M. Jiri, H. Wang, W. Liu, Q. Bao, Q. Lu, J. Zhang, F. Wang, H. Y. Xu, T. S. Sun, and H. P. Zhang. 2011. Diversity of lactic acid bacteria associated with traditional fermented dairy products in Mongolia. J. Dairy Sci. 94:3229-3241. https://doi.org/10.3168/jds.2010-3727.

\section{ORCIDS}

Aizhan Rakhmanova @ https://orcid.org/0000-0002-0129-7876

Xin Lü @ https://orcid.org/0000-0002-8624-0464 